\title{
MINORITY NATIONALISM AND SOCIALISM
}

\section{K. H. Wiik and the National Question in Finnish Social Democracy from 1900s to 1940s}

\author{
Matias Kaihovirta \\ Postdoctoral researcher, Political History, University of Helsinki
}

\section{Introduction: Ethnic identification and Swedish minority nationalism in Finnish social democracy}

First, we must abandon the notion that everything concerning national issues would be nationalism and therefore unworthy for a socialist. $^{1}$

These were the words used by the Swedishspeaking Finnish social democratic politician Karl Harald Wiik (1883-1946) in a speech he gave in 1921 in Helsinki for the Finnish Swedish-speaking social democrats. Wiik was, at the time, regarded as an expert on national issues within the Finnish Social Democratic Party (SDP). National issues were extremely relevant throughout Europe after the First World War, especially with the fall of the multinational Eastern- and Central-European empires. The rise of national issues lay in the ideological currents of nationalism and socialism, which had emerged during the 19th century and would considerably accelerate democratic developments in Europe during the 20th century. But national and ethnic issues also created new conflicts, wars and one of the cruellest genocides in human history that would take place at the heart of Europe. The question of the future role of the Swedishspeaking minority in Finland was one of many national issues in which the role of minorities in the post-First World War nationalising nation states became a political question. ${ }^{2}$ As this article will demonstrate, the future role of the Swedish-speaking minority would have a decisive impact on both Finnish domestic and foreign policy according to the Finnish Swedish-speaking socialist politician K. H. Wiik.

By studying Wiik and his role as a political and ideological foreground figure of the Swedish-speaking labour movement in Finland, this article aims to study the relationship between national issues, class and socialism in the history of the Finnish social democratic labour movement. This article problematises the language issue (in Finnish "kielikysymys" or in Swedish "språkfrågan") generally understood as a mere practical matter concerning the spoken language of the members and activists of the labour movement. In this article, language is connected to ethnic identity and nationalism. How was the question of ethnic

1 Karl H. Wiik, ”Den svenska befolkningen i Finland: Vår nationalitetsfråga och socialdemokratins ställning till densamma," Arbetarbladet, 8 April 1921.

2 Rogers Brubaker, Nationalism Reframed: Nationhood and the National Question in the New Europe (Cambridge University press, 1996), 55-60. 
identity connected to social democracy and socialist politics? What were the underlying conflicts and ideological solutions for linking national questions and socialism in the early $20^{\text {th }}$ century Finnish labour movement? My focus is on the politics dealing with ethnic identification and issues concerning national identity and the role it played not solely for the Swedish-speaking labour movement but for the historical development of Finnish social democracy and the multinational societal history of Finland.

Wiik was a significant individual and his uniqueness as a theoretically oriented politician and socialist internationalist and his conviction in the supremacy of Marxist thought, are issues which have been the focus of numerous historical studies of K. H. Wiik. ${ }^{3}$ In my research, the focus on Wiik illuminates the complexity of the relationship between socialism and nationalism. Wiik's involvement in issues concerning the Swedish-speaking minority within the Finnish labour movement reveals on a close reading how social democracy handled national issues, questions concerning ethnic minorities and the relationship between socialist internationalism and the nation state. In a comparative historical perspective, Wiik was in good company among many other contemporary socialist politicians, who were spending much time thinking and re-thinking the role of nation in working-class and socialist politics. For them, national issues were, as Wiik points out, not unworthy for a socialist; on the contrary, they were considered as extremely important for socialist politics. In existing research on the relationship between socialism and nationalism, it has been pointed out that a nation and nation state have been the framework for the labour movement on which to realise their political goals, e.g. the welfare state. ${ }^{4}$

However, the nation was not just instrumental for waging the class struggle for socialists, as some labour historians such as Eric Hobsbawm have wished to assert. ${ }^{5}$ Another more recent point of view is that the labour movement's class struggle has managed to include the struggle for national sovereignty whilst also contributing to the ideological content of nationalist movements and projects. The labour movement's relationship with nation and nationalism has at times in Marxist history been narrowly defined based on the words "the working men have no country" from the Communist Manifesto. This statement would, nevertheless, lead to a demand for popular democratic rights and freedoms for the working classes within the existing nation states in the $19^{\text {th }}$ and $20^{\text {th }}$ centuries. For some Marxists, the consolidation of the nation was regarded as a necessary step towards socialist internationalism. But, as some labour historians have demonstrated, the use of the concept of the nation fell in the multi-ethnic and multi-national social reality of the work-

3 Kalevi Pihanurmi \& Aimo Poutiainen, "Teoreetikko K. H. Wiik," in Tiennäyttäjät: Suomen työväenliikkeen merkkimiehiä Ursinista Tanneriin, vol. 3, ed. Hannu Soikkanen (Tammi: Helsinki, 1968); Erkki Tuomioja, K. H. Wiik, vol. 1, Itsenäisyysmies ja internationalisti: Elämäkerta vuoteen 1918 (Helsinki: Tammi, 1979); Seppo Hentilä, Veljeyttä yli pohjanlahden: Suomen ja Ruotsin työväenliikkeen kosketuskohtia suuresta Sundsvallin lakosta Suomen kansalaissotaan (Gaudeamus: Helsinki, 1980), 75-105; Erkki Tuomioja, K. H. Wiik, vol. 2, Puoluesihteeri ja oppositiososialisti: Elämäkerta 1918-1946 (Helsinki: Tammi, 1982).

4 Stefan Berger \& Angel Smith, "Between Scylla and Charybdis: Nationalism, Labour and Ethnicity Across Five Continents, 1870-1939," in Nationalism, Labour and Ethnicity 1870-1939, eds. Stefan Berger \& Angel Smith (Manchester: Manchester University Press, 1999), 1-30; John Schwarzmantel, "Nationalism and Socialist Internationalism," in The Oxford Handbook of the History of Nationalism, ed. John Breuilly (Oxford University Press, 2013), 639-646.

5 John Breuilly, "Eric Hobsbawm: Nationalism and Revolution," Nations and Nationalism 21, no. 4 (2015): 630-657, https://doi.org/10.1111/nana.12138. 
ing classes in most European countries in the early $20^{\text {th }}$ century, where ethnic divisions and conflicts restricted the practice of socialist internationalism in the everyday lives of workers. Therefore, socialists have not only applied civic but also ethnic understanding of the nation and how the working classes represent the "true" people of the nation. ${ }^{6}$

Wiik's significance for the Swedish-speaking labour movement cannot be underestimated. Both during his lifetime and after his death, he was celebrated and held a special place of admiration among Swedish-speaking socialists. For example, the dispute over Wiik's political heritage would lead to a severe divide in the Finnish-Swedish labour movement, which in turn threatened to have a serious impact on the entire SDP and its future during the postwar years in the late 1940s. ${ }^{7}$ However, the Swedish-speaking labour movement must not be reduced to a personality cult around $\mathrm{K}$. $\mathrm{H}$. Wiik; it was more the ideas he put forward that the members listened to and which they could relate to in their social and political reality. It has been claimed that the Swedish-speaking labour movement and working class faced a dual exclusion: as an ideological minority in the bourgeoisie dominated Finland-Swedish ethnic group and as a linguistic ethnic minority in the Finnish labour movement. Whilst Swedish-speaking socialists were undertaking a socialist class struggle against their bourgeoisie counterparts within the Swedish-speaking minority, they had to also stand up for their linguistic rights among the Finnish-speaking majority. ${ }^{8}$

This also opens up a perspective on social and minority national rights, which were at the centre of the political struggle of the Swedish-speaking labour movement, as a distinct form of what can heuristically be analysed as socialist minority nationalism. The significance of using minority nationalism as an analytical tool is to delineate a clear division between the concepts of the nation (as an ethnic-linguistic community) and the nation state (as a civic community including or excluding one or multiple nations). In Finland, the nation state construction was characterised by the ethno-lingual conflict between the Finnish and Swedish. However, a third category marking the bi-nationalist and civic characterisation of Finnishness ("suomenmaalaisuus" or "finländskhet") would develop as the official status for the bi-national ethnolinguistic neutral norm of citizenship in the Finnish nation state. These conflicting nationalisms in Finland are also a universal phenomenon in the history of nationalism, and, for example, Belgium and Canada have a similar history of bi-nationalism. ${ }^{9}$

In previous research, the SDP has been portrayed as neutral with regards to the "language issue", a perspective that lies partly in the party's own official language policy of Finland as a bilingual country and partly in the reconciliatory attitudes of prominent party leaders, such as Väinö Tanner, during the language conflict.

6 Håkan Blomqvist, Nation, ras och civilisation i svensk arbetarrörelse före nazismen (Carlssons: Stockholm, 2006), 105-129; Jakub S. Benes, Workers and Nationalism: Czech and German Social Democracy in Habsburg Austria, 1890-1918 (Oxford: Oxford University Press, 2017); Maarten van Ginderachter, The Everyday Nationalism of Workers: A Social History of Modern Belgium (Stanford University Press, 2019).

7 Matias Kaihovirta, Jonas Ahlskog \& Mats Wickström, "Minority Nationalism and Visions of Socialist Unity in the Post-War Finnish Labour Movement, 1944-1949," Labor History, Published online 22 September 2019, https://doi.org/10.1080/0023656X.2019.1666975.

8 Anna Bondestam \& Alf-Erik Helsing, Som en stubbe i en stubbåker: Finlands svenska arbetarförbund 18991974 (Helsingfors, 1978), 12-13, 164; Jan Sundberg, Svenskhetens dilemma: Finlandssvenskarnas samling och splittring under 1900-talet (Helsinki: The Finnish Society of Sciences and Letters, 1985), 88-93.

9 Jonas Ahlskog, Matias Kaihovirta \& Mats Wickström, "Nationen i klasskampen: Minoritetsnationalism inom den socialistiska arbetarrörelsen," Historisk Tidskrift, no. 3 (2018): 458-466. 
The Finnish historian Niko Kannisto has, with the help of contemporary theoretical nationalism research, discussed the SDP's relationship with the Finnish nation state nationalism in 1918-1930. However, his perspective takes a cautious - if not dismissive - approach to the ethnic dimension in the Social Democrats' attitude to and use of nationalism. ${ }^{10}$ Kannisto does not pay any notice to the Swedish-speaking labour movement in his study or its impact on the Finnish labour movement and in extension on the Finnish nation state.

The methodological approach for this article is based on political history that analyses discourses used in political processes and events in history. My aim is to illuminate, through the biographical and historical case of K. H. Wiik, the concepts of nationalism and socialism and to demonstrate how political discourse is used in a specific historical context. In other words, the biographical and personal history of Wiik is not the focus of study, rather his use of political ideas in relation to their historical context is. Therefore, I have chosen four case-studies, which can be regarded as the decisive years in the history of the Finnish labour movement and Finnish history in general. From the perspective of Wiik and the Swedish-speaking labour movement, which he at the time represented or was regarded as one of its forefront figures, the decisive years are 1905-06 (the general strike in November 1905 which led to the introduction of universal suffrage in Finland); 1918 (Finnish Civil War); 1926-27 (the first Social Democratic government in independent Finland), and 1940-41 (the time-period between the two wars Finland fought against the Soviet Union). These important landmarks in Finnish national historiography are examined within the aforementioned theoretical framework of socialist minority nationalism, represented through Wiik and the Swedishspeaking labour movement. The source material for this article includes texts written by Wiik, both speeches and articles, and they are analysed as a form of political action through speech acts ${ }^{11}$.

\section{Constituting Swedish-speaking socialist minority nationalism in 1906}

Swedish people have domiciliary right in this country, where Swedish has been spoken for as long as, and probably longer than, Finnish, and this principle must be adhered to. We have no obligation to sacrifice our Swedish language and our Swedish character for the sake of strayed nationalism; we are not even entitled to that. The importance of our Swedish workers in the future reform work is acknowledged among Finns, but we have also heard the request made that we should abandon our language in order to interact more intimately with Finnish-speakers. We will never accept such a claim [...]. If a language dispute arises - and it can only become defensive and justified on our part - Swedish workers have a place of priority among the other defenders of Swedishness. ${ }^{12}$

This statement by the young Swedish-speaking social democratic politician Karl H. Wiik, was published under the title "A Swedish social democratic party in Finland?" as the editorial article in the Swedish-speaking socialist newspaper Arbetaren (The Worker). It was a direct call for defending the rights of the Swedishspeaking population in Finland from the threat of Finnish nationalism. Wiik's editorial was a contribution to the newly arisen debate

10 Niko Kannisto, Vaaleanpunainen tasavalta? SDP, itsenäisyys ja kansallisen yhtenäisyyden kysymys vuosina 19181924 (Tampere: Työväen historian ja perinteen tutkimuksen seura, 2016).

11 Pasi Ihalainen, The Springs of Democracy: National and Transnational Debates on Constitutional Reform in British, German, Swedish and Finnish parliaments, 1917-1919 (Helsinki: Finnish literature society, 2017), $37-41$.

12 Karl H. Wiik, "Ett svenskt socialdemokratiskt parti i Finland?," Arbetaren, 26 May 1906. 


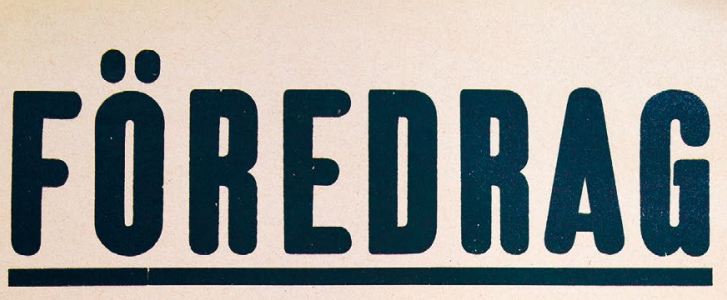

hålles av

socialdemokratiske partisekreteraren

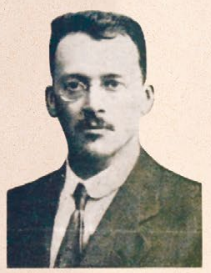

Karl H. Wiik

dagen den

\section{Möt talrikt upp, svenska arbetare och småbrukare!}

Poster of K. H. Wiik's lecture event. The text at the bottom of the poster reads: "Meet in large numbers, Swedish workers and small farmers!" The poster was printed in 1931. Photo:

The Finnish Labour Archives. to establish a Swedish social democratic party in Finland, an idea which Wiik at the time seemed to support, in order to defend the rights of Swedish-speaking workers.

It was Filemon Tiderman, Wiik's friend and editorial colleague in the newspaper Arbetaren, who presented, in his editorial article on 19 May 1906, the proposal to establish a Swedish social democratic party. Tiderman advocated a separation from the Finnish Social Democratic Party to strengthen social democratic mobilisation in Swedish in Finland. Firstly, he pointed out that the Swedish labour organisations were currently too weak both financially and in terms of active membership compared to the Finnish ones. Secondly, he emphasised the class differences among Swedish-speaking Finns, which prevented the social and economic rise of the Swedish proletariat and highlighted the Swedish upper class's low interest in workers' universal access to education. But above all, Tiderman emphasised the differences in the character of the two nationalities, the Finns and the Swedes, and 
Tiderman compared the situation with the developments in Austria and Russia where different nationalities and minorities had initially worked in a joint party but because of "differences in character and the obligation to defend their own language, a separation had become necessary." 13

The Swedish-speaking Social Democrats, organised in Finlands svenska arbetarförbund FSA (The Swedish Confederation of Workers in Finland) and founded in 1899, reacted against the alleged schisms between Finnishand Swedish-speaking workers, especially in bilingual social surroundings such as growing industrial towns and communities. The conflict had a long and complicated history, partly associated with language strives and the ethno-linguistic mobilisation of Finnish- and Swedish-speakers. ${ }^{14}$ But, in the early $20^{\text {th }}$ century, nationalist antagonism and ethnic rivalry were universal phenomena in the everyday lives of workers working and living in multinational social contexts. Helsinki and other industrial surroundings in Finland at the turn of the twentieth century resembled the industrial settings of multinational empires in Central and Eastern Europe, where workers of different ethnic and regional origin were competing against each other in the local labour markets. A nation and national identity were perceived as something concrete, which provided material benefits and resources to workers competing against migrants and workers of other regional, linguistic, religious, ethnic and national identities, but also, in terms of which ethnic group took precedence in the national social democratic labour movement, which could ultimately determine its ideological direction. This led to schisms tinted by nationalism, notedly in Austria-Hungary between German and Czech workers. ${ }^{15}$

In Finland, the conflicts were not as harsh as, for example, in Austria-Hungary, but in the Helsinki Swedish Workers' Association in the spring of 1906

[S] everal members of the Association announced how, in factories and workshops, the Finnish-speaking workers in every way showed their disdain for the Swedish, for the language and its speakers, who are considered as foreigners rather than Finns. ${ }^{16}$

Wiik recalled a year later, how the Swedishspeaking workers were mocked for their language, how their meeting notices in Swedish were destroyed by Finnish speakers and how they were not allowed to speak in bilingual workers' associations, which were dominated by Finnish-speaking workers. ${ }^{17}$ In addition, there were reports of increased anti-Swedish behaviour and Finnish nationalist verbal attacks on Swedish-speakers in connection to major labour meetings held in Eastern Finland. Thus, it was obvious that Swedish-speaking social democrats felt exposed by Finnish nationalism spread among Finnish-speaking workers which aimed to remove Swedish-speakers' right to their own language and culture. ${ }^{18}$

13 Filemon Tiderman, "I frågan om bildandet af ett svenskspråkigt socialdemokratiskt parti," Arbetaren, 19 May 1906.

14 Max Engman, Språkfrågan: Finlandssvenskhetens uppkomst 1812-1922 (Helsingfors: Svenska litteratursällskapet, 2016), 316-319.

15 Robert Stuart, Marxism and National Identity: Socialism, Nationalism, and National Socialism During the French Fin de Siécle (Albany: State University of New York Press, 2006), 49-50; Benes, Workers and Nationalism.

16 "Språkstrid inom Arbetarpartiet," Arbetaren, 21 April 1906.

17 K. H. Wiik, "Socialdemokratin bland Finlands svenskar," written in 1906 or 1907, Folder 7 FSA 1901-1914, K. H. Wiik's archive, The National Archives of Finland (KA), Helsinki.

18 Hannu Soikkanen, Sosialismin tulo Suomeen: Ensimmäisiin yksikamarisen eduskunnan vaaleihin asti (Helsinki: WSOY, 1961), 291-293. 
For Wiik and the FSA leadership, the antiSwedish nationalism being expressed by some Finnish-speaking social democrats after the national strike in 1905 was extremely worrying, because it threatened to weaken the spread of social democracy among Swedishspeakers, especially when the Swedish-speaking anti-socialist bourgeois opinion could easily depict the SDP and the social democrats as anti-Swedish and aspiring for the Finnification of Finland. ${ }^{19}$

Simultaneously, however, Wiik's editorial was under scrutiny by both Finnish-speaking social democrats and the leaders of the FSA. Wiik was accused of being a language demagogue and his statement was regarded as more suitable for the Swedish-speaking bourgeois press. The debate continued during the summer of 1906 and culminated in the FSA's first confederational conference held in July in Helsinki, when the Swedish-speaking social democrats would decide whether to start their own party or join the SDP. The decision was a unanimous rejection of the party plans, and Wiik also supported the proposal for the FSA to join the SDP - but with the demand that the position of Swedes as one of Finland's nationalities be recognised by the Finnish-speaking party majority. At the SDP's fifth party conference in Oulu, just over a month later, the party was reformed as a multinational party based on the principles of socialist internationalism that recognised the right of every nation to exist. Finnish, Swedish and Russian were recognised as Finland's three official nationalities and would have their own representation in the party, partly through their own district organisations and with permanent representation on the party board and other decision-making bodies. ${ }^{20}$
During the heated debate on the Swedishspeaking social democrats forming their own party, Wiik had also emphasised the importance of "Swedish character" as a key factor for a successful social democratic movement in Finland. In his editorial article on 26 May 1906 , he pointed out the differences in character that he felt existed between Finnish- and Swedish-speaking workers. In the editorial, Wiik highlighted that "Swedish workers are more considerate and less impressionable; they are better at exercising critical consideration rather than making hasty decisions" [...] whilst "among Finns" there was, according to Wiik, "a strong affection for ideas" which often stood in "a parade of poor judgements" ${ }^{21}$ According to this critical outlook on the Finns, the difference in the character of the two nationalities could be understood on the basis of the different levels of cultural evolution based on the Eurocentric ideas of scientific racism and social Darwinism, which was not at all uncommon in contemporary orthodox Marxist thinking. Wiik further pointed out that especially Finnish majority nationalism represented by the Finnish conservative party and referred to by the Swedish minority nationalists as "suometarianism" ("Fennomania") and later "äktfinskhet" ("true Finnishness"), was of Eastern origin, and the "servitude of the powerful and the oppression of the weaker" was characteristic of it. This characterisation of Finnish nationalism was a typical demarcation among Swedish minority nationalists and activists in their opposition to the ruling Finnish party and its loyalism to the Russian emperor. Social democracy, however, was considered to be of Western origin and, according to Wiik, more representative of the more "reflective" Swedish-speaking workers than the socio-culturally inferior Finns. ${ }^{22}$

19 Wiik, Arbetaren, 26 May 1906.

20 Soikkanen, Sosialismin tulo Suomeen, 293; Kannisto, Vaaleanpunainen tasavalta?, 587-588.

21 Wiik, Arbetaren, 26 May 1906.

22 Ibid.; See also: Engman, Språkfrågan, 330-333. 
Despite the fact that Wiik's Eurocentric and cultural evolutionist views of the differences between Swedish- and Finnish-speaking workers were met with strong opposition from both Finnish- and Swedish-speaking social democrats, the Oulu party conference would nevertheless comply with Wiik's ideas. The SDP's newly elected party chairman Edvard Valpas, who at first criticised Wiik for his dissident opinions and who Wiik in turn saw as one of the Finnish nationalists in the SDP ${ }^{23}$, echoed Wiik's cultural evolutionist approach in his speech at the conference in relation to the party's newly adopted position on the language issue:

Swedish is necessary for the Swedish population's improvement and also of great importance for the spread of Western culture and social democratic ideas in Finland, which is why the meeting proposes that Swedish culture should be maintained and promoted in Finland. ${ }^{24}$

The statement at the party conference undoubtedly pleased the Swedish minority nationalist Wiik. It expressed where he stood with the rebellion and corresponded with his demands, thus allowing the Swedish-speaking social democrats to accept the cooperation with the Finnish-speaking social democrats in a joint party. This statement, however, reinforced the idea that social democracy was a Western cultural movement and that the Swedes and Swedish culture played an important role in the establishment of its ideas in Finland. In addition to consolidating the role of the Swedish minority nation, it also recognised its role as a kind of Western avantgarde that would contribute to the successful dissemination of (Western) social-democratic ideas in Finland.

\section{Swedish-speaking Reds as victims of double oppression after the Civil War, 1918}

K. H. Wiik rejected the Social Democratic Party leadership's decision to initiate a revolution in the newly independent Finland in January 1918. Wiik's attitude to the Reds after the Civil War was, at first, a complete rejection. In his book Kovan kokemuksen opetuksia: sananen Suomen työväelle (Lessons on hard experiences: a few words to Finnish workers), published in November 1918 in Finnish, he employed a rhetoric reminiscent of the words he had used against those who had acted with violence during the national strike in 1905 . He claimed in 1918 that "the masses" had been "seduced by their hidden instincts", while accusing the then party leaders, which after the failed revolution went in exile, of lack of leadership for being attracted by the "inferior elements" among workers. ${ }^{25}$

In his book, Wiik was convinced of the economic and social certainties that would allow society's gradual transition into socialism. Wiik was at the time highly influenced by the Orthodox Marxist thoughts of Karl Kautsky, a personal friend to Wiik. In the Second International, historical materialism and the ideas of Darwin were closely linked and comparing the ideas of Marx with recent scientific discoveries became extremely popular in theoretical socialist debates. However, Kautsky's influential views on scientific Marxism were embedded in the Eurocentric view of the capitalist developments in Western Europe and the idea of the superiority of Western civilisation in the late $19^{\text {th }}$ and early $20^{\text {th }}$ centuries. ${ }^{26}$ The way Wiik saw it too, socialism developed in western European industrialised societies, and Wiik would position Finland in the gap be-

23 Soikkanen, Sosialismin tulo Suomeen, 293-294.

24 Citation from the congress protocol in: Bondestam \& Helsing, Som en stubbe i en stubbåker, 48.

25 Karl H. Wiik, Kovan kokemuksen opetuksia: Sananen Suomen Työväelle, 2nd ed. (Helsinki: Kansa, 1919), 12, $60,63$.

26 Blomqvist, Nation, ras och civilisation, 139-140. 
tween the socio-culturally undeveloped East and the developed West. The social democratic class struggle that took place in the new border states between Western Europe and Soviet Russia was the outpost of the civilised West against the wildness and cruelty of the East. As with some other western social democrats, Wiik envisaged the social democratic class struggle as part of the ongoing conflict between two different civilisations that was taking place in the aftermath of the First World War and the Bolshevik revolution. This was a struggle in which, according to the western social democrats, the western enlightened peoples and nations would prevail. According to Wiik, Finns possessed the cultural experiences that allowed the country to follow the western path because of its historical and cultural ties to Sweden - but the country's recent shared history with the authoritarian Czarist Russia had prolonged the social development, and the consequences had been fatal and resulted in the tragic events and outcomes of the failed Red revolution in 1917-18. ${ }^{27}$

Simultaneously, in a personal letter to Arvid Mörne in August 1918, Wiik expressed the views he was drawing on in his book on the failed Red uprising and emphasised in the letter (which was not apparent in the book) the ethnic aspect of the uprising by stating that

Regarding the time of the uprising, it is evident that Swedish workers committed murders in very few cases, and at that time, things were fairly calm in the Swedish countryside, excluding the non-locals. However, this testifies to the integrity of the Swedish character. ${ }^{28}$

Of course, this statement can be viewed as Wiik attempting to ingratiate himself with the minority nationalist Mörne, who had openly sympathised with the Whites during the Civil War, when Wiik had sought refuge with his former friend and mentor as he was hiding from the White authorities. However, this statement was much in line with Wiik's existing image of the Swedish-speaking social democrats as the more sensible ones who would not commit such brutal, uncivilised deeds as the Finnish-speaking workers had done.

If Wiik had been dismissive and expressed an extremely critical view of the Reds shortly after the Civil War, it might have changed as he became increasingly familiar with the horrors of the "White terror", which also hit hard on the Swedish-speaking labour movement. Returning to politics in the Spring of 1919 and visiting the local Swedish-speaking labour associations and taking part in the terror statistics, which the SDP was collecting at the time, seemed to have opened his eyes to the horrors "ordinary" social democrats had been facing during and after the Civil War, with murders, executions, prison camps and the full humiliation the members of the labour movement and their families were facing after the war. ${ }^{29}$ Twenty years later, in 1938, Wiik made the headlines in the Swedish-speaking press, when presenting for the very first time the terror statistics on the Swedish-speaking Red victims in 1918 and pointing out the fact that, among Finland-Swedes, the majority of the victims of the war had belonged to the Red side and been killed by Whites. Furthermore, most of them had died in prison camps or been executed rather than dying in combat. In other words, the Civil War had statistically affected Finland-Swedes in a similar way as Finnish-speakers, a fact that has long been denied in Finland-Swedish historiography. ${ }^{30}$

27 K. H. Wiik, "Österns och västerns princip," Arbetarbladet, 13 July 1919; K. H. Wiik, ”Den sociala kampen i Estland," Arbetarbladet, 19 August 1920; Blomqvist, Nation, ras och civilisation, 318-325.

28 Letter to Arvid Mörne, 14 August 1918, 28 Manuscripts 1838-1944, K. H. Wiik's archive, KA.

29 Bondestam \& Helsing, Som en stubbe i en stubbåker, 112-152, 162-183. 
However, already in a Finnish-speaking party publication celebrating the $25^{\text {th }}$ anniversary of the SDP, Wiik stated that the "reign of terror" had been more brutal in Swedish-speaking Finland during 1918, "because the Swedish-speaking upper classes were more brutal than the Finnish-speaking ones". The "destruction" exercised by the Swedishspeaking "slavers" had in many places been more thorough among the Swedish-speaking working-class minority. Therefore, according to Wiik, the Swedish-speaking workers faced a much tougher struggle to "liberate themselves from the leashes held by their upperclasses" than the Finnish-speakers. ${ }^{31}$

For Wiik and the Swedish-speaking social democrats, a strong identification with the Swedish minority-nation was still important. As a Swedish-speaking social democrat, Anna Bondestam (born Elfving) remembered how, in the years shortly after the Civil War, the Swedish-speaking social democrats had found it hard to identify themselves as accepted members of the newly born (White) Finnish nation state. Some felt that they had an even stronger bond to Sweden and Scandinavia rather than to Finnish Finland. ${ }^{32}$ Finnish ethnonationalism, which also appeared within the Finnish labour movement, prevented Swedish-speakers from integrating in the new Finnish nation state. Especially the social democratic newspaper editor Yrjö Räisänen aka Sasu Punanen was considered to be one of the "Fennomans" expressing critical antiSwedish opinions. ${ }^{33}$

Wiik took it as his primary task to counter the threat of Finnish nationalism within the
SDP. He sought to counteract the image that emerged in the Finnish social democratic view of Finland-Swedes as homogenous and as reactionary anti-democrats, by enlightening the party comrades of the double oppression experienced by the Swedish-speaking working class. This coincided with the language debate in the Finnish parliament and its decision to adopt the Language Act of 1922. Wiik and the FSA opposed the plans of the bourgeoisie Swedishspeaking minority nationalist Swedish People's Party (SFP) to preserve the Swedish minority nation by implementing self-governing Swedish areas on mainland Finland akin to the Åland Islands, and implementing a model based on the Swiss cantons. Wiik reminded them of the SDP's decision on the national issue that was taken as early as 1906 and which in practice was laid down in the Constitution in 1919, when the status of Finnish and Swedish as Finland's two national languages was confirmed. For the FSA and Wiik, the SFP's devolution idea was a major threat to the civil rights of the Swedish-speaking working class, because in these proposed self-governing areas, workers would be completely subordinate to the domination of the Swedish-speaking upper classes. ${ }^{34}$

In a cohesive bi-national Finland, the position of both Finnish- and Swedish-speaking workers could develop equally. Both the Constitution in 1919 and later the 1922 Language Act were a great disappointment to those who had promoted the Finland-Swedish autonomy and self-government, while the bi-nationalist line advocated by Wiik, among others, was victorious. Swedish-speaking workers, who,

30 "På sanningens bekostnad," Svenska Pressen, 8/1 1938; K. H. Wiik, "Våra svenska arbetare och inbördeskriget," Svenska Pressen, 12 January 1938.

31 Karl H. Wiik, "Sosialidemokratia Suomen ruotsalaisten keskuudessa," in. Sosialidemokraattinen puolue 25 vuotta: Muistojulkaisu (Helsinki: Sosialidemokraattinen puoluetoimikunta, 1924), 268-270.

32 Anna Bondestam, "Jag lever i republiken Finland," in Eldsjälar: Personporträtt ur finlandssvensk arbetarrörelse (Schildts: Esbo, 2000), 43-47.

33 Kannisto, Vaaleanpunainen tasavalta, 603-604.

34 "Socialdemokratin och nationalitetsfrågan," Arbetarbladet, 24 March 1926. 
despite their minority status, received equal civil status in the new Finnish nation state, were among the winners, according to Wiik. When the language issue was considered resolved, it was time for Wiik and the FSA to progress in national affairs to promoting the status of the bi-national Finnish working class and the defence of the democratic bi-national nation state.

\section{Defending the democratic bi-national nation state, 1926-1927}

In 1926, Wiik assumed a leadership role within the SDP as he was elected the party secretary, a position he would hold for a decade (1926-36) during a very turbulent period in the history of both Finland and Europe. This was also the highlight of Wiik's political career and the first time a Finland-Swedish social democrat managed to assume a role of leadership within the SDP (excluding bilingual Edvard Gylling, who briefly held the position of the vice-chair in 1917-18 ). During Wiik's time as the party secretary, the SDP would also enter the government for the first time during Finland's independence, forming a social democratic minority cabinet under the former party chairman Väinö Tanner, who, thus, became the prime minister. The social democratic cabinet was short lived. It held office only for a year, but its significance in constructing a "democratic front" against the right-wing anti-socialist reaction and the threat of fascism was an important milestone in Finnish political history.

The backbone of the Finnish right had since 1918 been the Finnish conservative National Coalition Party (NCP) and the SFP. However, the position of the Swedish minority in Finland created a rift between these two leading right-wing conservative parties, which provided an opportunity for the SDP to start cooperating with the SFP, since the SDP was formally a bilingual party and supported Swedish minority rights. The conservative right-wing within the SFP was challenged by a group called the Swedish Left, which formed an independent party faction after the Civil War, and its leading figures included Georg Schauman and Max Hanemann, both of whom had been acquainted with Wiik during their radical student years in the early 1900 s. The relationship between the SFP and the SDP undoubtedly improved as the party secretary was well acquainted with the prominent representatives of the SFP's left faction, which shared many views on Swedish minority rights and the need for social reform for the FinlandSwedes. But Wiik and the Finland-Swedish social democrats were, as mentioned earlier, critical of the idea of self-government which was advocated by the Swedish left. ${ }^{35}$

On 22 November 1926, the cooperation between the SDP and the SFP was consolidated when the Finnish bourgeois government led by the agrarian Kyösti Kallio was overthrown as a result of an interpellation in parliament by the SFP with the Swedish left's Schauman as the first signatory. Tanner's government, formed shortly after, also had the support of the Communist Party and the Liberal Progress Party in parliament. ${ }^{36}$ During Tanner's reign, Wiik maintained an active correspondence with the Socialist Labour International's (SAI) secretary-general Friedrich Adler from Austria. Wiik presented the ideological and political positions behind the Finnish social democratic government policies. He emphasised that Tanner's government was characterised by the Finnish right as "the unpatriotic coalition", the right's pejorative term for the government and its support-

35 Bondestam \& Helsing, Som en stubbe i en stubbåker, 34; Göran von Bonsdorff \& Frank Jernström, Svenska folkpartiet, vol. 2, 1917-1929: Från självständighet till Lappo (Svenska folkpartiet, 1984), 155-158.

36 Sven Lindman, De homogena partiregeringarna i Finland 1926-1928, vol. I, Det socialdemokratiska regeringsexperimentet 1926-1927 (Åbo: Åbo Akademi, 1940), 11-21. 
parties, which Wiik with great irony seemed to embrace. Wiik described to Adler the government as "a defence against the chauvinistic tendencies found in the Finnish bourgeoisie." As an argument for this, Wiik cited the kind of aggressive policies the Finnish bourgeois parties had brought against not only the working classes but also the Swedish minority in Finland with discriminatory legislation in recent years against the Finland-Swedes. ${ }^{37}$

In July 1927, parliamentary elections were organised in Finland, which resulted in an election victory for the government and its support parties. The Social Democrats' campaign had urged Swedish-speaking voters to cast their vote for either the SDP or the SFP to prevent the "True Finnish crusade" against the Swedish minority. ${ }^{38}$ After the election, a satisfied Wiik reported to the SAI that despite the "Finnish-national" NCP's attempts to overthrow the government, the turnout of the election had "ensured a painful defeat for the Finnish bourgeoisie." The defence of the Swedish minority was so far secured with the positive result for the government, Wiik wrote, and the support of the SFP would stave off "the Finnish bourgeois reaction" attacking democracy. ${ }^{39}$ But, at the same time, Wiik acknowledged the challenges of the "democratic front", admitting it was weak, because, in the prevailing class interests, the bourgeois faction of the SFP had more in common with the "chauvinistic" Finnish-bourgeois parties than with the working-class parties of the SDP and the Communists. ${ }^{40}$
At first, the Swedish Social Democratic Party Secretary was in the firing line for his outspoken socialist internationalism. In the Finnish political right, the SDP was criticised for letting the Finnish social democrats choose a "Swedish man" to its leadership, while newspapers mocked the appearance of Wiik who, with "his narrow face and gloomy and sharp eyes behind glasses, evokes images of Finland's eastern neighbour's famous agitators". The fierce criticism the true Finns directed at Wiik and the Finland-Swedes from an ethno-nationalistic true Finnish perspective was reminiscent of anti-Semitic rhetoric as it compared Finland-Swedes to Jews and their alleged world conspiracy and anti-nationalism. Just as the Jews were claimed to rule the "international proletariat dictatorship" in the Soviet Union, the Finland-Swedes had apparently undermined the unity of the Finnish people through the Finnish labour movement. ${ }^{41}$

Interestingly enough, when Finnish fascism through the Lapua Movement and the Patriotic People's Movement (Isänmaallinen kansanliike) rose in the 1930s, the FSA openly warned that Finland-Swedes were under a fascists threat along with other vulnerable minorities, especially the Jews. ${ }^{42}$ However, Wiik and the FSA also underlined that under the threat of fascism it was important to cooperate beyond class boundaries within the Swedish-speaking minority to safeguard the Swedish language in Finland and to maintain the country within the cultural sphere of the Nordic countries and the democratic Western world. ${ }^{43}$

37 Letter to Friedrich Adler, 11 May 1927, K. H. Wiik's correspondence 1923-1937, SDP Archive, The Labour Archives (TA), Helsinki.

38 Arbetarbladet, 29 June 1927.

39 Letter to SAI, 1927, K. H. Wiik's correspondence 1923-1937, SDP Archive, TA.

40 Letter to Friedrich Adler, 11 May 1927, SDP Archive, TA.

41 "Parlamenttipakinaa," Karjala, 18 February 1926; "Ruotsalainen mies sosialidemokraattienkin johtoon," Aitosuomalainen, no. 3 1926, 49.

42 "Svensk dag med dissonanser," Arbetarbladet, 11 November 1938.

43 "En svensk resolution mot Lappo," Arbetarbladet, 19 September 1930; "Lappo och vänstern i Sverge," Åbo Underrättelser, 21 September 1930. 


\section{The great unpatriotic war and questioning the concept of Fatherland, 1940-1941}

You shall love your country so that no patriotic speeches can stifle your love. ${ }^{44}$

After his resignation as the party secretary in 1936 and before the outbreak of the Second World War in 1939, Wiik was regarded as one of the prominent figures in the SDP's left-wing opposition, and he became a leading critic of Finland's wartime political leadership. Wiik and the left-wing opposition were particularly critical of Väinö Tanner and the fact that, before the war, the SDP endorsed a defence budget increase and actively cooperated with the right in wartime state leadership. Wiik's resistance and role as a kind of socialist opposition leader would lead to his arrest among many other left-wing activists and communists following the outbreak of the Continuation War, when Finland fought as a co-belligerent with Nazi-Germany against the Soviet Union in 1941-44. Wiik was sentenced to high treason and imprisoned. After Finland entered into separate peace with the Soviet Union in September 1944, Wiik was released, and, together with other opposition socialists and the Social Democrats and the re-legalised Communist Party, he founded the new Suomen Kansan Demokraattinen Liitto SKDL (Finnish People's Democratic League), which became a sort of anti-fascist leftist umbrella organisation under communist dominance with the aim to build a new socialist Finland after the war. ${ }^{45}$

Wiik challenged the bourgeois concept of the Fatherland before the outbreak of the Second World War which, according to him, had also been accepted by the SDP leadership under Tanner. Interestingly, he did not reject the concept of Fatherland as such but pointed out the fallacy of the bourgeoisie's use of the concept as an argument for the rearmament of the Finnish army in the late 1930s. K. H Wiik and his wife Anna Wiik, who was also an active member of FSA and an outspoken Swedish-speaking social democratic antifascist, opposed defence spending approved by the social democratic and agrarian coalition government. According to K. H. and Anna Wiik rearmament was not, as the party leaders of SDP had claimed, to build up a defence for democracy against the threat of fascism "because Finland was not a fully democratic state". K. H. Wiik pointed out that the army officer corps consisted of fascist elements, and he paid much attention to the recruitment of new army officers. According to him, the army needed a cleansing of fascist elements in order to strengthen the democratic values of the officer corps. A cleansing of fascist elements in the Finnish army would reduce the suspicion of the sincere neutrality of the Finns in the eyes of the Soviet Union and improve the relations with neighbouring democratic Sweden. ${ }^{46}$

Wiik's argument was based in part on internationalist socialist ideas from the early 1900s, which claimed that proletarian internationalism was the true safeguard for the salvation of the Fatherland rather than the bourgeoischauvinistic nationalism and militarism. $\mathrm{He}$ also argued that the task of the social democrats was to enlighten the working classes, the petty-bourgeoisie and the peasant-class of the capitalist interests that lay behind the war, which he had advocated ever since the threat of war was within sight in Europe towards the end of the 1930s: "many of us also fear the false patriotic demagoguery, and our most

44 Karl H. Wiik, "Några tänkespråk: Nedskrivna i fängelserna i Riihimäki och Åbo hösten 1943," Arbetarbladet,

8 July 1946.

45 Tuomioja, Puoluesibteeri ja oppositiososialisti, 189-202, 211-213, 233-244, 264-334, 352-358.

46 "Efterskörd från FSA 21 kongress," Arbetarbladet, 16 April 1938. 
important task is to expose it." ${ }^{47}$ In the socialist newspaper Vapaa Sana (Free Word), which Wiik had launched and edited with the socalled group of six ("kuutoset") in 1940-41, he emphasised that true patriotism and devotion to the Fatherland was in keeping with socialist proletarian internationalism and not bourgeois capitalism that sought to oppress the working classes and other nations. ${ }^{48}$ This included the oppression of smaller nations and minorities, which had made fascism, especially for the socialist Swedish-speaking minority, so repulsive and why, at the early stages, the FSA had demonstrated to their supporters the link between true-Finnish ethnonationalism and fascism.

The antifascist rhetoric Wiik, but mostly the FSA, had employed before the outbreak of the Second World War, had enabled the further democratisation of Finland-Swedishness, meaning that the Swedish-speaking minority was regarded as a sort of guarantee for democracy against the totalitarian threat of Stalinism, Nazism and Fascism. This somewhat echoed the criticism Wiik had directed earlier at "authoritarian" Finnish majority nationalism and the alleged role Swedishness had in defending the values of Western civilisation and (social) democracy in Finnish society, which in turn was considered to be the ultimate defence of ethnic minorities and the working class. The Finland-Swedish labour movement became divided as a result of the war. Some Swedishspeaking grassroot social democrats later stated that Wiik's exclusion from the SDP in the fall of 1940 had given them a particular reason to follow in his footsteps and subsequently, after the war, join his newly formed People's
Democratic movement. ${ }^{49}$ Wiik's legacy in the Finland-Swedish labour movement, but also among some leading Finland-Swedish bourgeois post-war politicians ${ }^{50}$, was connected to Wiik's antifascism shortly before the outbreak of the Second World War and his opposition of the war, especially his resistance to the alleged morally dubious Continuation War.

\section{Conclusion: \\ Socialist minority nationalism and internationalism in the history of Finnish social democracy}

Studying the Swedish-speaking socialist politician Karl H. Wiik and his role in four selected periods in the history of the Finnish labour movement has highlighted the Swedish-speaking working class minority's role and perspective in the historical development of the Finnish socialist labour movement in the first half of the $20^{\text {th }}$ century. The key outcome of the study is to link the commonly discussed "language issue" with matters of ethnic identification and socialism and to show how these two were interconnected in the Swedish-speaking labour movement, which K. H. Wiik represented. As the Austrian social democratic politician and theorist Otto Bauer stated in his great study "The Question of Nationalities and Social Democracy", national character was something real, a distinctive part of social reality. By recognising national differences and accepting national sovereignty (which was not, in the Austro-Marxian perspective, the same as the sovereignty of nation states), working classes of different national origin could be bound together in international solidarity.

47 K. H. Wiik, "Eriävä mielipide," 8 January 1939, 16 1939, K. H. Wiik's archive, KA; Tuomioja, Puoluesihteeri ja oppositiososialisti, 280-284.

48 K. H. Wiik, "Oikeaa ja väärää isänmaallisuutta," Vapaa Sana, 16 August 1940; K. H. Wiik, "Internationalism och fosterlandskärlek", manuscript for "Nyårshälsning till Finlands svenska arbetare och bönder," 1940, 10 Vapaa Sana 1940-41, K. H. Wiik's archive, KA.

49 ”Atomkriget måste förhindras säger 90-åriga Artur Eklöv," Ny Tid, 10 November 1983.

50 Jan-Magnus Jansson, Tidiga möten: Litteratur och politik frän 30-tal till 60-tal (Esbo: Schildts, 1996), 123. 
While the Austro-Marxists referred to the multi-ethnic and multi-national reality of the Habsburg empire, Wiik used this framework for the multi-national (or later after the Finnish independence bi-national) reality in Finland. Swedish-speaking workers were to be recognised as a distinctive nation with its own ethnic and cultural identity, which differed from the Finnish-speaking majority. By giving the Swedish-speaking minority identity progressive and socialist content and by combining ethnic and cultural understandings of Swedishness and linking it to contemporary cultural understandings of the superiority of the Western European civilisation, the Swedes in Finland could, according to Wiik, have a greater influence on the character of the Finnish bi-national society as a whole and on building a (social)democratic Finnish bi-national nation state. Wiik showed that between the Finnish majority and Swedish minority there were ethnic tensions leading to political conflicts that could emerge in severe ideological disagreements, but that assuming Internationalism as the guiding principle could bridge national conflicts and create unity in the common socialist class struggle.

Using the analytical concept of minority nationalism, this article has shown how the agents of the socialist labour movement could effectively combine socialist politics with (minority) nationalist projects, which is a contribution to the research on the history of the relationship between nationalism and socialism. On a more general level, concepts, such as minority nationalism or nations without states, problematise the theology of nation state nationalism, which has also dominated much of previous labour historical research on the relationship between socialism and nationalism.

\section{Bibliography}

\section{Archival Sources}

National Archives of Finland (KA), Helsinki. K. H. Wiik's Archive.

The Labour Archives (TA), Helsinki. SDP Archive.

\section{Newspapers}

Aitosuomalainen 1926

Arbetaren 1906

Arbetarbladet 1919, 1920, 1921, 1926, 1927, 1930, 1938, 1946

Karjala 1926

Ny Tid 1983

Svenska Pressen 1938

Åbo Underrättelser 1930

\section{Articles and Books}

Ahlskog, Jonas, Matias Kaihovirta, \& Mats Wickström. "Nationen i klasskampen: Minoritetsnationalism inom den socialistiska arbetarrörelsen." Historisk Tidskrift, no. 3 (2018): 452-479.

Benes, Jakub. Workers and Nationalism: Czech and German Social Democracy in Habsburg Austria, 1890-1918. Oxford: Oxford University Press, 2017.

Berger, Stefan, \& Angel Smith. "Between Scylla and Charybdis: Nationalism, Labour and Ethnicity Across Five Continents, 1870-1939." In Nationalism, Labour and Ethnicity 1870-1939, edited by Stefan Berger \& Angel Smith, 1-30. Manchester: Manchester University Press, 1999.

Blomqvist, Håkan. Nation, ras och civilisation i svensk arbetarrörelse fore nazismen. Stockholm: Carlssons, 2006.

Bondestam, Anna. "Jag lever i republiken Finland." In Eldsjälar: Personporträtt ur finlandssvensk arbetarrörelse, 43-47. Esbo: Schildts, 2000.

Bondestam, Anna, \& Alf-Erik Helsing. Som en stubbe $i$ en stubbåker: Finlands svenska arbetarförbund 1899-1974. Helsingfors, 1978.

Von Bonsdorff, Göran, \& Frank Jernström. Svenska folkpartiet. Vol. 2, 1917-1929: Från självständighet till Lappo. Svenska folkpartiet, 1984.

Breuilly, John. "Eric Hobsbawm: Nationalism and Revolution." Nations and Nationalism 21, no. 4 (2015): 630-657.

Brubaker, Rogers. Nationalism Reframed: Nationhood and the National Question in the New Europe. New York: Cambridge University Press, 1996. 
Engman, Max. Språkfrågan: Finlandssvenskhetens uppkomst 1812-1922. Helsingfors: Svenska litteratursällskapet i Finland, 2016.

Van der Ginderachter, Maarten. The Everyday Nationalism of Workers: A Social History of Modern Belgium. Stanford: Stanford University Press, 2019.

Hentilä, Seppo. Veljeyttä yli pohjanlahden: Suomen ja Ruotsin työväenliikkeen kosketuskohtia suuresta Sundsvallin lakosta Suomen kansalaissotaan. Helsinki: Gaudeamus, 1980.

Ihalainen, Pasi. The Springs of Democracy: National and Transnational Debates on Constitutional Reform in British, Swedish and Finnish parliaments, 19171919. Helsinki: Finnish Literature Society, 2017.

Jansson, Jan-Magnus. Tidiga möten: Litteratur och politik frän 30-tal till 60-tal. Esbo: Schildts, 1996.

Kaihovirta, Matias, Jonas Ahlskog, \& Mats Wickström. "Minority Nationalism and Visions of Socialist Unity in the Post-War Finnish Labour Movement, 1944-1949." Labor History, Published online 22 September 2019.

https://doi.org/10.1080/002365

6X.2019.1666975.

Kannisto, Niko. Vaaleanpunainen tasavalta? SDP, itsenäisyys ja kansallisen yhtenäisyyden kysymys vuosina 1918-1924. Tampere: Työväen historian ja perinteen tutkimuksen seura, 2016.

Lindman, Sven. De homogena partiregeringarna i Finland 1926-1928. Vol. 1, Det socialdemokratiska regeringsexperimentet 1926-1927. Åbo: Åbo Akademi, 1940.
Pihanurmi, Kalevi, \& Aimo Poutiainen. "Teoreetikko K. H. Wiik.” In Tiennäyttäjät: Suomen työväenliikkeen merkkimiehiä Ursinista Tanneriin. Vol. 3, edited by Hannu Soikkanen, 265-311. Helsinki: Tammi, 1968.

Schwarzmantel, John. "Nationalism and Socialist Internationalism." In The Oxford Handbook of the History of Nationalism, edited by John Breuilly, 635-654. Oxford: Oxford University press, 2013.

Soikkanen, Hannu. Sosialismin tulo Suomeen: Ensimmäisiin yksikamarisen eduskunnan vaaleihin asti. Helsinki: WSOY, 1961.

Sundberg, Jan. Svenskhetens dilemma i Finland: Finlandssvenskarnas samling och splittring under 1900-talet. Helsinki: The Finnish Society of Sciences and Letters, 1985.

Stuart, Robert. Marxism and National Identity: Socialism, Nationalism, and National Socialism During the French Fin de Siécle. Albany: State University of New York Press, 2006.

Tuomioja, Erkki. K. H. Wiik. Vol. 1, Itsenäisyysmies ja internationalisti: Elämäkerta vuoteen 1918. Helsinki: Tammi, 1979.

Tuomioja, Erkki. K. H. Wiik. Vol. 2, Puoluesihteeri ja oppositiososialisti. Helsinki: Tammi, 1982.

Wiik, Karl H. Kovan kokemuksen opetuksia: Sananen Suomen työväelle. Helsinki: Kansa, 1919.

Wiik, Karl H. "Sosialidemokratia Suomen ruotsalaisten keskuudessa." In Sosialidemokraattinen puolue 25 vuotta. Muistojulkaisu, 261-272. Helsinki: Sosialidemokraattinen puoluetoimikunta, 1924. 